\title{
Customer's Perception and Expectation for Reverse Logistics Implementation
}

\author{
Farida Pulansari, Dwi Sukma Donoriyanto, Nisa Masruroh \\ Department of Industrial Engineering, Faculty of Industrial Engineering Technology \\ Universitas Pembangunan Nasional "Veteran" Jawa Timur, \\ Raya Rungkut Madya, Surabaya, Indonesia \\ pulansari@gmail.com
}

\begin{abstract}
Good communication between buyers and sellers are important strategy for company to maintain the customer satisfaction, loyalty, and enhance financial performance. Complaint is a signal that indicates important information that needs quick response. On the other hand, environmental problems (i.e. waste, unused product and limitation of natural resources) become growing concern through the decade. This paper proposed House of Reverse Logistics (HRL) for connecting between customer needs and environmental problems. HRL effectively can minimize the customer complaint. Literature showed that Customer Needs and Reverse Logistics (RL) are effective method to solve these problems. The design of HRL was adopted from Quality Function Deployment (QFD)
\end{abstract}

Keywords- Reverse Logistics, Customer Perception, Quality Function Deployment

\section{INTRODUCTION}

Our environment is constantly changing. Pollution, global warming, Natural Resource Depletion, Natural Resource Depletion, Loss of Biodiversity, Climate change, Deforestation, Ocean Acidification and Ozone Layer Depletion are major current environmental problems. Some regulation released to solve these problems. For example: Directive 2002/96/EC on Waste Electrical and Electronic Equipment and Directive 2002/96/EC on the Restriction of the Use of Certain Hazardous Substances in EEE (RoHS) [1].

To response the environmental problems, company needs to consider some regulations such as: corporate imaging, social responsibility, legislation, economic benefit and customer awareness. Focuses on customer awareness, companies need strategy to maintain the customer satisfaction and loyalty [2].

Communication between buyers and sellers is central to the supply chain philosophy [3]. Lee et al., [4] reported complaint is signaling that indicate the important information from customer as major indicator of customer dissatisfaction. If companies can be ignored the complaints, the migration of profitable customers can be minimized [5]. Hence, companies need identifying the customer complaints, and need planning recovery strategies to maintain customer satisfaction and enhance financial performance $[6 ; 7 ; 8]$.

We adopted RL and QFD method to understanding the customer needs. Reverse Logistics (RL) basically not only a process of planning, process and implementation, but also controlling raw material, finished good and waste management.
At this time, only few papers covers environmental issues as customer needs in QFD methods. QFD usually used to develop strategy, to help implant methods, to product development to develop software, to develop services and to help planning [9]. QFD is one technique to deal with customer needs and expectation [10]. In other hand, QFD is mechanism for translating the voice of customer into the language of engineers [11]. A study from Yilmaz et al., [12] report that complaint management is affected by two factors, namely, customer response and organizational learning. Further, [13] concluded that QFD is effective methods to translate customer needs into engineering characteristics.

In this research, we purpose House of Reverse Logistics (HRL) to understanding the customer perception and expectation for Reverse Logistics (RL) implementation. This approach successfully meets customer requirement (environmental problems especially reverse logistics problems) into engineering characteristics to develop company strategic and to maintain customer satisfaction and loyalty.

\section{REVIEW OF THE LITERATURE}

\section{A. Reverse Logistics (RL)}

Pokharel and Mutha [2] reported RL research studies began in the 1960s. Every decade, RL topic was change appropriate with problems in that time. The RL topics can be seen in the Figure 1. At the beginning, RL research focused on production planning, network design and RL model. Interaction between sustainability and supply chain by considering environmental issues was focused in 2000s. In the last decade, RL topics focused on product life extension, product recovery at end-oflife, waste management, secondary material, sustainability environmental and customer satisfaction.

RL research has classified into four perspectives since the 1960s until 2008s [2].The four perspectives are RL Inputs, RL Process, RL Structure and RL Outputs. Several issues from RL Inputs are selection of raw materials, safety stock, forecast and inventory systems $[14 ; 15 ; 16 ; 17]$. The purpose of this perspective is mechanism preparation of raw material. For RL Process, the topic focused on disassembly product, product return process, modelling systems remanufacturing management and coordinated along supply chain actors $[18 ; 19$; 20 ; 21]. In other hand, [22], [23] and [24] focused on infrastructure design, and capacity production. RL Structure discussed on location and allocation planning [25; 26; 27; 28]. 
The last perspective is RL Output. RL Output discussed about pricing, revenue management, product competition and service information $[29 ; 30 ; 31]$. Further, we adopt the new perspective to covers some research has not adopted in the RL perspective. The namely of new perspective is RL Social and Organization. The topics focused on return policies, stakeholders, organizational slack, market competition, third parties logistics, and decision model and process $[32 ; 33 ; 34 ; 35 ; 36 ; 37 ; 38 ; 39$; $40 ; 41]$.

\section{B. Quality Fuction Deployement (QFD)}

QFD is a method of converting the customers' requirement and developing a design quality of the finished product by systematically [42]. Same definition proposed by [43] and [10] QFD is a systematically method to response the customers' wants and needs with structural products planning and innovation. In other hand, [44] concluded that QFD is a method which has strong relationship between producing the new product and product development to accommodate consumers' expectation. Further, [11] reported that QFD is a mechanism to translating the voice of customer into to language of engineers..

\section{REVERSE LOGISTICS IN INDONESIA}

Indonesia today has been one of Development County with the most consistent growth rates. Based on [45], growth of household consumption in Indonesia, which accounts for about 57 percent of the nation's overall economic growth, fell to 4.94 percent (y/y) in Q1-2016 (from a 5.01 percent y/y growth pace one year earlier). This is a cause for concern and alarm because controlled inflation as well as low energy prices should have caused rising household consumption rather than slumping consumption growth. With the household consumption level, Indonesia have many kinds problems in environmental. For the example is electronics waste from household consumption. In the other hand, companies must be managing customer satisfaction and loyalty too. Research by [46] reported that Indonesian household wastes reach the highest percentage (43, $4 \%)$. Other sources waste from market $(20 \%)$, street $(9 \%)$, public facility $(9 \%)$, office $(8 \%)$, industry $(6.5 \%)$ and others (4.6\%). Hence, [47] reported, since 2007, Indonesian electronics manufacturers have produced more than 3 billion units of household appliance and IT equipment. While the annual consumption of TV reaches up to 4.3 million units, refrigerators at 2.1 million, air conditioning and washing machine at 900.000 units. Further, this research is very important to minimize electronics waste with understanding the customers' needs and wants.

\section{RESEARCH METHODOLOGY}

The purpose of this research is to design HRL and attribute of customer needs and wants (RL Inputs, RL Process, RL Structure, RL Output and RL Social and Organization). The customer needs design was derived from QFD methods. RL implementation perception will added in Matrix WHATs. Next step is design of Technical Response (Matrix HOWs) to response the customer requirement. Furthermore, the next step same with design of House of Quality (HOQ). Planning Matrix will divided into 7 steps i.e. Importance to customer, Customer Satisfaction Performance, Goal, Improvement Ratio, Sales
Point, Raw Weight and Normalized Raw Weight. Finally, Technical Matrix consists of Contribution, Normalized Contribution and Rank

\section{RESULTS \& DISCUSSIONS}

PCB Company is the object for this research. PCB Company is consumers Electronics Company. Line business PCB is produces electronics household such as: Audio Cassette Tape, Color TV, AC, Washing Machine, TV Rack, CD Replication Services, and Plastic Injection Services.

Respondent in this survey is Akari consumers' who already use the Akari household product. The survey was conducted in Akari-Pusat Reparasi Indonesia (PRI) and Association Service Center (ASC) to collect the criteria of customer requirement. Also, we discuss with customer as end users directly to understanding customer wants and needs. The highest complaints record comes from 1 PRI and 6 ASC. The PRI comes from Surabaya (PRI-Surabaya). Hence, complaints come from Gresik (ASC-UD.Duta Bina Teknik), Malang (ASC-Windra Service), Mojokerto (ASC-Mandiri Service), Krian (ASC-Adhi Citra Elektronik), Pasuruan (ASC-NR Elektronik) and Surabaya (ASC-Yohasa Service). After conducting a series brainstorming sessions with RL Expert, Company, Service Center, Consumers, and Government Regulation for e-waste, we found $16^{\text {th }}$ most important complaint criteria would influence customers' satisfaction of RL Implementation (Table 1).

TABLE I. CUSTOMER REQUIREMENT

\begin{tabular}{|c|c|c|}
\hline $\begin{array}{c}\text { RL } \\
\text { Perspective }\end{array}$ & & Attribute of Customer Requirement \\
\hline RL Inputs & $\begin{array}{l}\text { A1 } \\
\text { A2 }\end{array}$ & $\begin{array}{l}\text { New, used products (parts) or recycled material } \\
\text { Outsourcing Reverse Logistics activities }\end{array}$ \\
\hline RL Structure & $\begin{array}{l}\text { B1 } \\
\text { B2 } \\
\text { B3 }\end{array}$ & $\begin{array}{l}\text { Locating facilities for returned used products } \\
\text { Integration of collection, inspection and } \\
\text { consolidation of used products } \\
\text { Integration manufacturing and remanufacturing }\end{array}$ \\
\hline RL Process & $\begin{array}{l}\mathrm{C} 1 \\
\mathrm{C} 2 \\
\mathrm{C} 3 \\
\mathrm{C} 4 \\
\mathrm{C} 5\end{array}$ & $\begin{array}{l}\text { Disassembly mechanism } \\
\text { Reverse Logistics Information Technology } \\
\text { Management } \\
\text { Handling heterogeneous parts for production } \\
\text { Scheduling arrivals mechanism for new modules, } \\
\text { storing, or disposing } \\
\text { Repair and after-sales service }\end{array}$ \\
\hline RL Outputs & $\begin{array}{l}\text { D1 } \\
\text { D2 } \\
\text { D3 }\end{array}$ & $\begin{array}{l}\text { Pricing the remanufactured product } \\
\text { Customer retention and satisfaction } \\
\text { Enhanced service quality }\end{array}$ \\
\hline $\begin{array}{l}\text { RL Social and } \\
\text { Organization }\end{array}$ & $\begin{array}{l}\text { E1 } \\
\text { E2 } \\
\text { E3 }\end{array}$ & $\begin{array}{l}\text { Company strategic and policy (include } \\
\text { organizational slack) } \\
\text { Marketing interfaces and leasing } \\
\text { The Return Policy }\end{array}$ \\
\hline
\end{tabular}

Next step is calculation the planning matrix and technical matrix. 


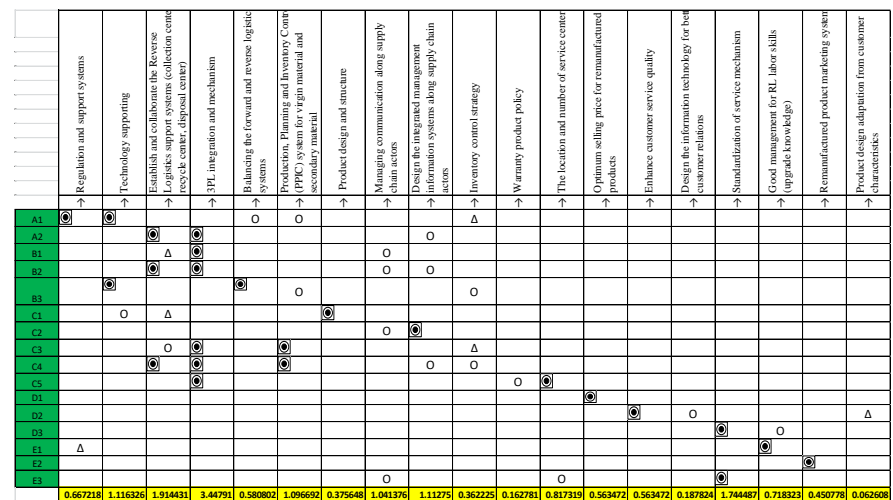

Fig. 1. QFD Analysis for RL Implementation

Statistical test for questionnaire result is valid and reliable. The value of Cronbach's Alpha is 0.885 . The $\mathrm{r}$ calculation is higher than $r$ table $(0.4555)$ with $\mathrm{DF}=15$ with the confidence level at $95 \%$. Next step is calculation the planning matrix and technical matrix.

The Relationship Matrix in Figure 1 explain about scale 0, $1,3,9$, where 9 corresponds to a very strong relationship, 3 to a strong, 1 to a weak and 0 to no relationship. The rating 9 is three times as strong as rating 3 or nine times as strong as rating 1. As an example (column 1), the weighting of Centre of gravity is gained as follows: (Normalized Raw Weight $x$ Scale) $=(0.07 \times 9)+(0.05 \times 3)=0.667$. The analyses are shown in (Fig. 1).

The purpose of calculating the overall weighting is to identify those characteristics (RL Implementation) that are influencing the customer satisfaction to the greatest extent. A high overall weighting may preferably be gained if there is a strong relationship between the service characteristic and customer needs with a high customer rank.

The purpose of this research is to fulfill the customer needs and wants and minimize customer complaint [5]. Table 2 shows that the targets must be priority by company (the highest result) are 3PL integration and mechanism $(0.20298=20,298 \%)$, Establish and collaborate the Reverse Logistics support systems (collection center, recycle center, disposal center) (0.11270-11,270\%), Standardization of service mechanism (0.10270-10,270\%), Technology supporting $(0.06572-6,572 \%)$, Design the integrated management information systems along supply chain actors (0.06551$6,551 \%)$ and others $>45 \%$.
TABLE II. TARGET PRIORITY

\begin{tabular}{|c|c|c|c|}
\hline Technical Response & Contribution & $\begin{array}{l}\text { Normalized } \\
\text { Contribution }\end{array}$ & Targets \\
\hline Regulation and support systems & 0.67 & 0.03928 & 10 \\
\hline Technology supporting & 1.12 & 0.06572 & 4 \\
\hline $\begin{array}{l}\text { Establish and collaborate the Reverse Logistics support systems (collection center, } \\
\text { recycle center, disposal center) }\end{array}$ & 1.91 & 0.11270 & 2 \\
\hline 3PL integration and mechanism & 3.45 & 0.20298 & 1 \\
\hline Balancing the forward and reverse logistics systems & 0.58 & 0.03419 & 11 \\
\hline $\begin{array}{l}\text { Production, Planning and Inventory Control (PPIC) system for virgin material and } \\
\text { secondary material }\end{array}$ & 1.10 & 0.06456 & 6 \\
\hline $\begin{array}{l}\text { Product design and structure } \\
\end{array}$ & 0.38 & 0.02211 & 15 \\
\hline Managing communication along supply chain actors & 1.04 & 0.06131 & 7 \\
\hline Design the integrated management information systems along supply chain actors & 1.11 & 0.06551 & 5 \\
\hline Inventory control strategy & 0.36 & 0.02132 & 16 \\
\hline Warranty product policy & 0.16 & 0.00958 & 17 \\
\hline The location and number of service center & 0.82 & 0.04812 & 9 \\
\hline Optimum selling price for remanufactured products & 0.56 & 0.03317 & 12 \\
\hline Enhance customer service quality & 0.56 & 0.03317 & 13 \\
\hline Design the information technology for better customer relations & 0.19 & 0.01106 & 15 \\
\hline Standardization of service mechanism & 1.74 & 0.10270 & 3 \\
\hline Good management for RL labor skills (upgrade knowledge) & 0.72 & 0.04229 & 8 \\
\hline Remanufactured product marketing systems & 0.45 & 0.02654 & 14 \\
\hline Product design adaptation from customer characteristics & 0.06 & & \\
\hline
\end{tabular}

\section{CONCLUSION}

A new mechanism based on Reverse Logistics Systems and QFD methods has been developed to understanding the customer needs and wants. This approach will help company to understanding the complaint from customers. Complaint is a signal that indicates important dissatisfaction information. Also, complaints are an indicator of some problems. QFD will help company to priority of targets which has strong impact for company sales and performance. Based on QFD result, company needs to plan recovery strategies to maintain the customers' satisfaction and loyalty

\section{ACKNOWLEDGMENT}

We gratefully thank DP2M DIKTI (Directorate of Higher Education) Ministry of Education, Indonesia though "Hibah Bersaing" Research Grant 2016 for supports this research. Research Batch I No: SPP/12/UN.63.8/LIT/III/2016, entiled "Disain Framework of Reverse Logistics Maturity Level Menuju Kondisi Environmental Friendly, Green Product, Eco Efficiency dan Government Control \& Policy pada Klaster Industri Elektronika Konsumsi”

\section{REFERENCES}

[1] Orgalime, A practical Guide to understanding the scope of , Directive 2002/96/EC on Waste Electrical and Electronic Equipment (WEEE) and Directive 2002/95/EC on the Restriction of the Use of Certain Hazardous Substances in EEE (RoHS), Orgalime Guide, 2006, p2-12.

[2] Pokharel, S., Mutha, A., Perspectives in reverse logistics: A review, Resources, Conservation and Recycling, 2009, p175-182.

[3] Ellinger, A. E., Daugherty, P. J., Plair, Q. J., Customer satisfaction and loyalty in supply chain: the role of communication, Transportation Research Part E, 1997, p121-134.

[4] Lee, C.-H., Wang, Y.-H., Trappey, A. J. C., Ontology-based reasoning for the intelligent handling of customer complaints, Computers \& Industrial Engineering, 2015, p144-155.

[5] Filip, A., Complaint management: A customer satisfaction learning process, Procedia - Social and Behavioral Sciences, 2013, p271-275.

[6] Varela-Neira, C., Vasquez-Casielles, R., Iglesias, V., Explaining Customer Satisfaction with Complaint Handling, International Journal of Bank Marketing, 2010, p88-112.

[7] Vinodh, S., Devadasan, S. R., Vimal, K. E. K., Kumar, D., Design of agile supply chain assessment model and its case study in an Indian automotive components manufacturing organization, Journal of Manufacturing Systems, 2013, p620-631.

[8] Cambra-Fierro, J., Melero, I., Sese, F. J., Managing Complaints to Improve Customer Profitability, Journal of Retailing, 2015, p109-124. 
[9] Carnevalli, J. A., Miguel, P. C., Review, Analysis and Classification of the Literature on QFD - Types of Research, Difficulties and Benefits, Int. J. Production Economics, 2008, p737-754.

[10] Dikmen, I., Birgonul, M. T. and Kiziltas, S., Strategic use of quality function deployment (QFD) in the construction industry, Building and Environment, 2005, p245-255.

[11] Kim, D.-H., Kim, K.-J., Robustness indices and robust prioritization in QFD, Expert Systems with Applications, 2009, p2651-2658.

[12] Yilmaz, C., Varnali, K., Kasnakoglu, B.T., How the firms benefit from customer complaints, European Journal of Operational Research, 2016, p944-955.

[13] Kuijt-Evers, L. F. M., Morel, K. P. N., Eikelenberg, N. L. W., Vink, P., Application of the QFD as a design approach to ensure comfort in using hand tools: Can the design team complete the House of Quality appropriately?, Applied Ergonomics, 2009, p519-526.

[14] Minner, S., Startegic safety stocks in reverse logistics supply chain, Int. J. Production Economics, 2001, p417-428.

[15] Pati, R. K., Vrat, P., Kumar, P., Economic analysis of paper recycling vis-a` -vis wood as raw material, Int. J. Production Economics, 2006, p489-508.

[16] Donghong, Y., Yujie, T., Hui, L., The Research on the Inventory Cost Control of Return Reverse Logistics, International Conference on Information Management, Innovation Management and Industrial Engineering, IEEE, 2008.

[17] Peng, B., Pan, Y., Pan, F., Study on Inventory Control Model of Reverse Logistics for Products in Declining Periods, International Conference on Electronics Commerece and Business Intelligence, IEEE, 2009.

[18] Kleber, R., Minner, S., Gudrun,. K., A continuous time inventory model for a product recovery system with multiple options, Int. J. Production Economics, 2002, p121-141.

[19] Hu, T-L., and J.-B. S., Huang, K-H., A Reverse Logistics Cost Minimization Model For The Treatment of Hazardous Wastes. Transportation Research Part E, 2002, p457-473.

[20] Dobos, I., Optimal production-inventorystrategies for a HMMS-type reverse logistics system, Int. J. Production Economics, 2003, p351-360.

[21] Yalabik, B., Petruzzi, N. C., Chhajed, D., An integrated product returns model with logistics and marketing coordination, European Journal of Operational Research, 2005, p162-182.

[22] Shih, L.-H., Reverse logistics system planning for recycling electrical appliances and computers in Taiwan, Resources, Conservation and Recycling, 2001, p55-72.

[23] Bayındır, Z. P., Erkip, N., Güllü, R., Assessing the benefits of remanufacturing option under one-way substitution and capacity constraint, Computers \& Operations Research, 2007, p487-514.

[24] Qu, X., Williams, J. A. S., An analytical model for reverse automotive production planning and pricing, European Journal of Operational Research, 2008, p756-767.

[25] Kara, S., Rugrungruang, F., Kaebernick, H., Simulation modelling of reverse logistics networks. Int. J. Production Economics, 2007, p61-69.

[26] Neto, J. Q. F., Bloemhof-Ruwaard, J. M., Nunen, J. A. E. E. V., Heck, E. V., Designing and evaluating sustainable logistics networks, Int. J. Production Economics, 2008, p195-208.

[27] Lee, D.-H., Dong, M., Dynamic network design for reverse logistics operations under uncertainty, Transportation Research Part E, 2009, p61-71.

[28] Kenne ', J-P., Dejaz, P., Gharb, A., Production planning of a hybrid manufacturing-remanufacturing system, Int. J. Production Economics, 2012, p81-93.
[29] Mitra, S., Revenue management for remanufactured products, Omega, 2007, p553-562.

[30] Liang, Y., Pokharel, S., Lim, G. H., Pricing used products for remanufacturing, European Journal of Operational Research, 2009, p390-395.

[31] Vadde, S., Zeid A., Kamarthi, S.V., Pricing decisions in a multi-criteria setting for product recovery facilities, Omega, 2011, p186-193.

[32] Richey, R.G, Chen, H., Genchev, S.E., Daugherty, P.J., Developing effective reverse logistics programs, Industrial Marketing Management, 2005, p830-840.

[33] Álvarez-Gil, M.J.,Berrone, P., Husillos, F.J., Lado, N., Reverse logistics, stakeholders' influence, organizational slack, and managers' posture, Journal of Business Research, 2007, p463-473.

[34] Kumar, S., Putnam, V., Crandle to crandle: Reverse logistics strategies and opportunities across three industry sectors, Int. J. Production Economics, 2008, p305-315.

[35] Cheng, Y-H., Lee, F., Outsourcing reverse logistics of high-tech manufacturingfirms by using a systematic decision-making approach: TFT-LCD sector in Taiwan, Industrial Marketing Management, 2010, p1111-1119.

[36] Azadi, M., Saen, R.F., Comprehensive performance measurement and causal-effect decisionmaking model for reverse logistics enterprise, Computers \& Industrial Engineering, 2011, p87-103.

[37] Tavana, M., Zareinejad, M., Caprio, D.D., Kaviani, M.A., An integrated intuitionistic fuzzy AHP and SWOT method for outsourcing reverse logistics, Applied Soft Computing, 2016, p544-557.

[38] Guarnieri, P., Sobreiro, V.A., Nagano, M.S., Serrano,A.L.M., The challenge of selecting and evaluating third-party reverse logistics providers in a multicriteria perspective: a Brazilian case, Journal of Cleaner Production, 2015, p209-219.

[39] Rezaei, J., A systematic review of multi-criteria decision-making applications in reverse logistics, Transportation Research Procedia, 2015, p766-776.

[40] Vahabzadeh, A.H., Asiaei, A., Zailani, S., Green decision-making model in reverse logistics using FUZZY-VIKOR method, Resources, Conservation and Recycling, 2015, p125-138.

[41] Agrawal, S., Singh, R.K., Murtaza, Q., Outsourcing decisions in reverse logistics: Sustainable balanced scorecard and graph theoretic approach, Resources, Conservation and Recycling, 2016, p41-53.

[42] Akao, Y., Quality Function Deployement: Integrating Customer Requirement into Product Design, Portland, Productivity Press, 1990.

[43] Cohen, L., Quality Function Deployement : How to Make QFD Work For You, Massachusetts, Addition-Wesley Publishing Company, 1995.

[44] Govers, C. P. M., What and how about quality function deployment (QFD), Int. J. Production Economics, 1996, p575-585.

[45] Indonesia-Investment, Indonesian Government Release Official GDP Growth Figure for the Year, 2012, Accesessed: http://www.indonesiainvestments.com/news/news-columns/indonesian-government-releasesofficial-gdp-growth-figure-for-the-year 2012/item473? searchstring=household $\% 20$ consumption

[46] Meidiana, C., Gamse, T., Development of Waste Management Practices in Indonesia, European Journal of Scientific Research, 2010, p199-210.

[47] Hanafi, J., Kristina, H. J., Christiani, A., Halim, A. V., Santoso, D., Melini, E., The prospects of managing WEEE in Indonesia, The 18th CIRP International Conference on Life Cycle Engineering, Braunschweig, Germany, 2011, p492-496. 